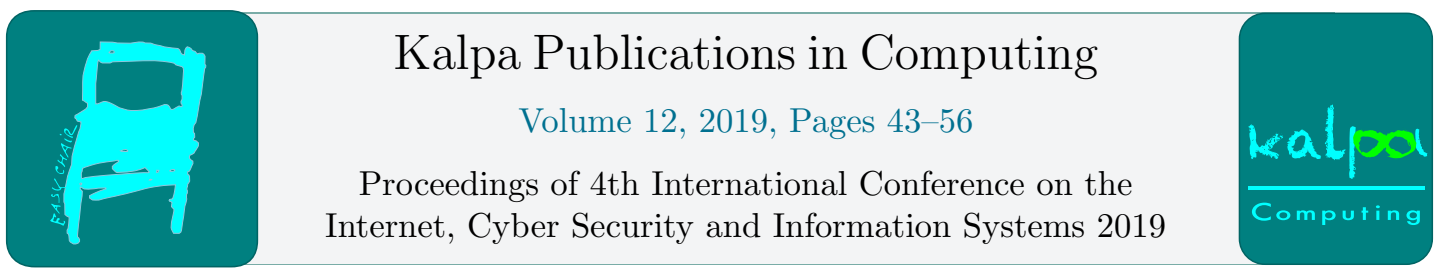

\title{
Modeling the adoption of cloud computing to assess South African SMEs: An integrated perspective
}

\author{
Kenneth Tewan Ayong ${ }^{1}$ and Rennie Naidoo ${ }^{2}$ \\ University of Pretoria, South Africa \\ ayongkenneth@gmail.com, rennie.naidoo@up.ac.za
}

\begin{abstract}
The adoption of cloud computing among SMEs in developing countries, particularly South Africa, is still very low. The purpose of this study is to develop a conceptual model to assess the critical factors that influences South African SMEs to adopt cloud services. This paper proposes an integrated conceptual model that incorporates critical factors from the diffusion of innovation (DOI) theory, institutional theory, transaction cost theory, organisation theory, information security theory, and trust theories. Cloud computing adoption research dominated by the DOI perspective, can benefit from further crossfertilization with different theories to explain and predict patterns of cloud services use in the SME context. This model is expected to offer deeper insights and practical value to SME decision makers, cloud service providers, regulatory agencies and government responsible for establishing cloud computing adoption strategies for SMEs in South Africa. We intend to apply this model to survey research in future studies.
\end{abstract}

Keywords: Cloud computing, adoption, SMEs, trust, conceptual model

\section{Introduction}

In the fourth industrial revolution era, cloud technology has brought about new complexities and uncertainties increasing the role of trust relationships between partners [1] [2]. Cloud computing is a utility service that deliver Information Technology (IT) services to consumers through the Internet enabling Small and Medium-sized Enterprises (SMEs) to technologically compete with their larger counterparts, on a pay-as-you-use service without any initial significant financial investment. Attracting and retaining customers is a financial imperative for cloud technology providers. Several researchers have attempted to explain why individuals and organisations adopt new technology using many factors such as, trust [3] [4] [5], security and privacy factors [6] [7], cost-benefit and ease of use while to a lesser extent institutional factors [8] [9]. This study proposes an integrated conceptual model to explain 
the critical success factors that influences cloud services adoption by SMEs in South Africa. In addition, this study examines the mediating role of trust as a primary reason why SMEs adopt cloud computing. The integration of these relevant adoption theories enhances the explanatory power of our model to clarify the phenomenon of cloud computing adoption by SMEs in developing economies [10]. The research questions for this study are:

Q1. What are the critical adoption factors that will influence SME organisations' intention to adopt cloud services?

Q2. Does trust in cloud computing services mediate the relationships between the adoption factors and intention for an SME to adopt such services?

To answer the research questions posed above, this study identifies the critical adoption factors and establishes the mediating role of trust in cloud on the adoption intention of cloud services by SMEs in RSA. This study further introduces an integrated conceptual model and develops propositions for future research by drawing on the perspectives of diffusion of innovation (DOI) theory, transaction cost theory, information system security theory, organisational theory, institutional theory and trust theories.

The structure of the paper is as it follows. Section 2 discusses the background of cloud computing, literature review and the theoretical foundation of this study. Section 3 presents the proposed conceptual model and hypotheses for cloud computing adoption for South African SMEs. Section 4 presents a conclusion, recommendations and future research.

\section{Background}

\subsection{Cloud definition}

An Oracle report on the path to transform to fourth IR technologies, found that out of 1,200 technology managers of medium and large enterprises sampled across the Middle East and Africa, $60 \%$ stated that an integrated cloud approach will reveal the potential of disruptive technologies for businesses, such as block chaining, business analytics, robotics and artificial intelligence [11]. Today's cloud technology is not only for storage and scalability but used to enable the backbone of new technology such as real-time data analytics, AI, machine learning, IoT and block chain which organisations of all sizes are taking advantage of for its growth, sustainability and survival.

Many definitions of cloud computing has been highlighted in literature, but the most prominent definition was provided by the American National Institute of Standards and Technology (NIST) as "a model for enabling convenient, on-demand network access to a shared pool of configurable computing resources (e.g. networks, servers, storage, applications, and services) that can be rapidly provisioned and released with minimal management effort or service provider interaction." [12, p. 2]. Cloud computing is composed of five essential characteristics (on-demand self-service, ubiquitous network access, location independent resource pooling, rapid elasticity, and measured service); three service delivery models (Software as a Service [SaaS], Platform as a Service [PaaS], and Infrastructure as a Service [IaaS]); and three models for enterprise access (Private cloud, Public cloud, and Hybrid cloud)." [12].

Cloud technology has many advantages but also a variety of challenges, such as cybersecurity, hacking, privacy risks, lack of technical knowledge, limited interoperability, limited data portability, lack of trust due to loss of control and ignorance [1]. Previous research has established that online purchase intentions are as a result of the consumer's cost return assessments of the transaction, the trust in the online ecosystem and technology providing the services [3]. This can be extended to transactions that result in the adoption and use of cloud computing services. 


\subsection{Existing literature}

The differences between SMEs and large enterprises with respect to organisational size, knowledge of technology, organisational structure and organisational turnover requires SMEs to be treated differently from large enterprises in their relationships with cloud providers and cloud adoption. Trust is considered an effective means for overcoming the increasing complexity of technology and organisational interactions required in establishing relationships [14]. Extant cloud computing adoption literature for SMEs has been limited to adoption models for SMEs by considering both business and technical requirements [15] [16]. Other studies have highlighted cloud computing services adoption factors that influence decision makers in both large enterprises and SMEs [17] [18]. Nevertheless, due to the inconclusiveness of these studies, there is a need to understand cloud adoption factors using a combination of theories and the role of trust in establishing such transactions and maintaining them. A number of researchers have grounded their study on transaction cost theory and return on investment though without any empirical tests concluded that cost reduction was a significant factor in decision making by SMEs to adopt cloud computing [19] [20]. Most studies on SME adoption in developing economies have focused their assessments on a limited number of adoption drivers without exploring and testing the mediating role of trust. Identifying the direct drivers of SME cloud adoption is important, however understanding how these may be influenced by possible mediating effects of trust is also crucial. It is therefore important to understand the role of mediating factors in adoption decisions and more work is required to understand how mediating factors could influence factors that play a direct role in SME cloud adoption decisions in developing economies.

\subsection{Drivers emerging from the literature}

We performed a systematic literature review using scholarly databases such as ACM, IEEE, Science direct, Springer link, ProQuest, EBSCOHost, Google Scholar and Emerald Insight, from which we selected 71 well cited published articles for review. Various factors influencing the cloud computing adoption decision were identified, such as cost reduction, convenience, reliability, collaboration, security, privacy, relative advantage, top management support, competitive pressure, service provider, complexity, compatibility, technical knowledge, trust, awareness, ease of use, perceived usefulness, risks, organisation size, regulatory support, infrastructure and trialability. Table 1 below lists some empirically tested studies on cloud computing adoption in developing economies and highlights the significant drivers influencing cloud computing adoption decision making.

\begin{tabular}{|c|c|c|c|c|}
\hline Authors & $\begin{array}{l}\text { Adoption } \\
\text { theory }\end{array}$ & $\begin{array}{l}\text { Factors affecting cloud computing } \\
\text { adoption }\end{array}$ & Country & $\begin{array}{l}\text { Research } \\
\text { method/ } \\
\text { design }\end{array}$ \\
\hline$[21]$ & AHP & $\begin{array}{l}\text { Security, privacy, Top management support, } \\
\text { Relative advantage, Competitive pressure }\end{array}$ & $\begin{array}{lr}110 & \text { Indian } \\
\text { SME } & \text { decision } \\
\text { makers } & \\
\end{array}$ & $\begin{array}{l}\text { Qualitative \& } \\
\text { quantitative }\end{array}$ \\
\hline$[22]$ & TAM & $\begin{array}{l}\text { Ease of use and Convenience, Reliability, } \\
\text { collaboration, Security and Privacy, Cost } \\
\text { reduction }\end{array}$ & Malaysia & A mix method \\
\hline$[23]$ & $\begin{array}{l}\text { (TOE, DOI, } \\
\text { TAM). }\end{array}$ & $\begin{array}{l}\text { Ease of use and Convenience, Reliability, } \\
\text { Sharing and collaboration, Security and } \\
\text { Privacy, Cost reduction Security, Top } \\
\text { management support, Firm Size }\end{array}$ & $\begin{array}{l}289 \text { Indian } \\
\text { SME managers }\end{array}$ & Quantitative \\
\hline$[24]$ & DOI & $\begin{array}{l}\text { Complexity, Compatibility, Trialability, } \\
\text { Technical }\end{array}$ & 110 Moroccan & $\begin{array}{l}\text { Quantitative, } \\
\text { Survey }\end{array}$ \\
\hline [25] & DOI & Compatibility, Complexity, knowledge & SMEs & Survey \\
\hline$[6]$ & (DOI, TOE) & $\begin{array}{l}\text { Readiness, Security, Technical barrier, } \\
\text { Enterprise size, Top management support, } \\
\text { Organisation readiness, Enterprise status, }\end{array}$ & $\begin{array}{l}\text { Saudi Arabian } 81 \\
\text { SME companies }\end{array}$ & $\begin{array}{l}\text { Comparative } \\
\text { study }\end{array}$ \\
\hline
\end{tabular}


Modeling the adoption of cloud computing to assess South African SMEs:... K. Ayong and R. Naidoo

\begin{tabular}{|c|c|c|c|c|}
\hline & & $\begin{array}{l}\text { Industry sector, Competitive pressure, External } \\
\text { support, Government support, Relative } \\
\text { advantage, Compatibility, Complexity }\end{array}$ & & \\
\hline [26] & $\begin{array}{c}\text { TOE } \\
\text { framework. }\end{array}$ & $\begin{array}{l}\text { Relative advantage, Top management support, } \\
\text { Complexity and compatibility, Firm size, } \\
\text { Competitiveness }\end{array}$ & $\begin{array}{l}220 \text { ICT officers } \\
\text { Kenyan }\end{array}$ & Questionnaires \\
\hline [27] & UTAUT & Perceived ease of use, Perceived usefulness - & $\begin{array}{ll}103 & \text { Saudi } \\
\text { Arabian } & \\
\end{array}$ & Quantitative \\
\hline [4] & $\begin{array}{l}\text { TAM and } \\
\text { TOE }\end{array}$ & $\begin{array}{l}\text { Organisation size, Industry, Top management, } \\
\text { IT resources, IT competencies, perceive ease of } \\
\text { use, Perceive usefulness, Trust, Credibility, } \\
\text { Risk, Familiarity, Competitive pressure, } \\
\text { External support }\end{array}$ & $\begin{array}{l}\text { South African } 73 \\
\text { SME decision } \\
\text { makers }\end{array}$ & $\begin{array}{l}\text { Questionnaires } \\
\text { and interviews }\end{array}$ \\
\hline [19] & TCE & Cost reduction & India & \\
\hline [28] & $\begin{array}{l}\text { TOE } \\
\text { framework and } \\
\text { ANT. }\end{array}$ & $\begin{array}{l}\text { Cost, Savings, Relative advantage, Lack of } \\
\text { data, Privacy, data security, Compatibility, } \\
\text { knowledge }\end{array}$ & 67 Malaysian & Questionnaire \\
\hline [29] & $\begin{array}{l}\text { Institutional } \\
\text { theory, the } \\
\text { capability } \\
\text { approach, }\end{array}$ & $\begin{array}{l}\text { Government regulations, Competitive pressure, } \\
\text { SME organisational capability }\end{array}$ & $\begin{array}{l}\text { Nigeria and } \\
\text { Ethiopia }\end{array}$ & $\begin{array}{l}\text { Interview } 10 \\
\text { SME decision } \\
\text { makers }\end{array}$ \\
\hline [30] & $\begin{array}{l}\text { TAM } \\
\text { TOE }\end{array}$ & $\begin{array}{l}\text { Facilitating conditions, Habit, Performance } \\
\text { expectancy, Price, effort expectancy, Social } \\
\text { influence, Lack of motivation, Inadequate } \\
\text { security }\end{array}$ & $\begin{array}{l}\text { Ghanaian SMEs } \\
\text { managers }\end{array}$ & Quantitative \\
\hline [31] & (DOI). & $\begin{array}{l}\text { Relative advantage, Compatibility and Cost } \\
\text { reduction }\end{array}$ & $\begin{array}{ll}101 & \text { Pakistani } \\
\text { SMEs } & \end{array}$ & Survey \\
\hline [7] & (TOE) & $\begin{array}{l}\text { Top management support, Security, Privacy, } \\
\text { Cost, Trading partner and Competitor pressure }\end{array}$ & $\begin{array}{c}\text { Malaysian } \\
41 \text { enterprises } \\
\end{array}$ & Survey \\
\hline$[32]$ & $(\mathrm{TOE})$ & $\begin{array}{l}\text { Security, Data privacy, Cost effectiveness, } \\
\text { Internet reliability, Top management support, } \\
\text { Competitive pressure }\end{array}$ & $\begin{array}{l}\text { 300 SMEs in } \\
\text { Malaysia }\end{array}$ & Survey \\
\hline$[20]$ & $\begin{array}{l}\text { (ROI) and } \\
\text { (TCT) }\end{array}$ & Security; Reliability, Trusting & Asia & Exploratory \\
\hline
\end{tabular}

Table 1: Extant empirical literature on cloud computing adoption amongst SMEs in Developing economies.

To assess individual choice, prior research applied the technology acceptance model (TAM) [33], the unified theory of acceptance and use of technology (UTAUT), and the theory of planned behaviour (TPB) [34]. Prior research has also used the technology organisation and environment theory (TOE) to explain organisational adoption decisions. However, despite its extensive use in IS adoption studies and the consistent empirical support it has enjoyed, TOE has major conceptual overlaps with DOI characteristics hence not considered in this study.

The integrated conceptual model that incorporates critical factors from the diffusion of innovation (DOI) theory, institutional theory, transaction cost theory, organisation theory, information security theory, and trust theories which is consistent with the significant adoption factors identified in extant literature as listed in Table 1 above. Understanding how these drivers interact with the mediating role of trust to influence adoption of cloud computing remain theoretically and practically important avenues for research.

\subsection{Diffusion of Innovation Theory (DOI)}

DOI theory by Rogers [35] is a timeline-based theory in explaining why and how organisation adopt new technology. DOI theory have been used by many studies to understand organisations adoption of new technology, however, this theory does not consider the influence of existing trust deficit in the regulatory, supplier and competitor environment of the organisation. According to Rogers [35], the 
adoption intention is influenced by the perception of the new technology on the following characteristics:

Relative advantage describes a situation where the new technology is perceived to be superiority than those that it supersedes. The competitive advantage of a new technology is especially important for SMEs where competition is high, and resources are limited and would adopt any alternative new technology that improves productivity and offers some economic benefit. Compatibility which refers to perception of consistency of the new technology with existing technology and experiences. Complexity refers to the relative difficulty of which the new technology is to understand and use compared to the previous one. Trialability is the ability for the new technology to be tested.

According to Rogers [35], the three steps towards a decision to adopt a new technology as depicted in figure 1 below are; knowledge, persuation and decision. Knowledge of the new innovation such as cloud computing begins when top management or a product champion is exposed to it benefits thereby initiating a trust building process with the technology. Once there is understanding about its functionality and business benefits, the next step is to persuade them to consider adopting the new technology by considering adoption factors. Some cloud service providers provide a trial version of the technology to expedite the persuasion process. Trialability of the technology enhances the persuation efforts through understanding the suitability of the attributes of the technology.

A decision is made when top management and a product champion's trust in the new technology is matured and are convinced that the attributes of the new technology are favourable to the organisation. This study argues that trust is a dynamic continuum mechanism through which the adoption variables are able to influence the decision to adopt cloud compting. From initiation, to building trust through persuations, to maturity or declining trust when decisions are made as illustrated by process model of cloud adoption in figure 1 below.

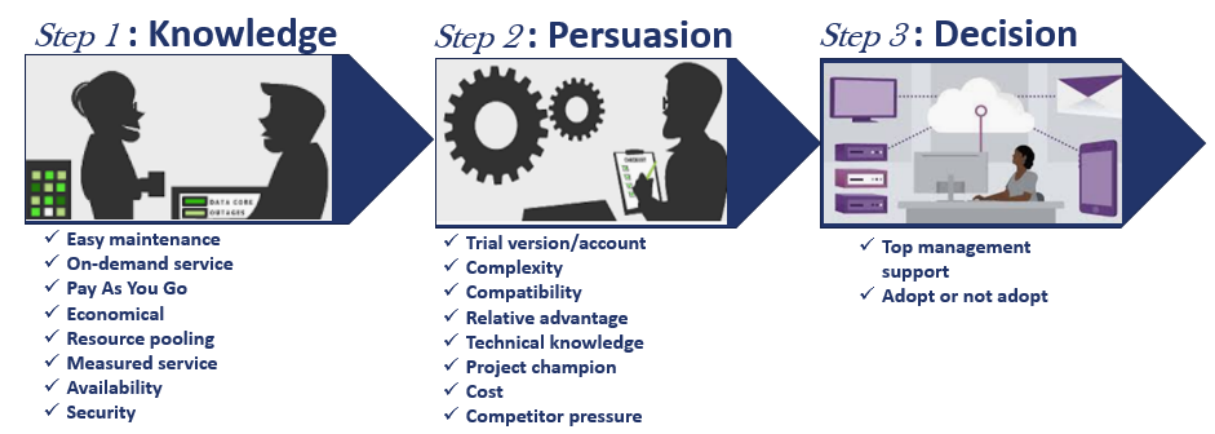

Figure 1: The process model of cloud adoption, adapted from Rogers. [36] [35]

\subsection{Trust theory}

Researchers have identified many dimensions of trust such as " the key to understanding the relationship development process" [37, p. 32] to being "a glue that holds the relationship together" [38, p. 156]. Many other disciplines have identified trust as a key component in its literature such as psychology and behavioural science [39] [40]), sociology and institutional literature [41] [42], technology and agency approaches [43] [44] economic and game theory [42], and organisational literature [40] [43] [5]. In the discipline of Information Systems, there are multiple definitions and approaches to the trust concept, its antecedents and consequents [13] [3] [41]. These studies have two common themes: confident expectations by the trustor that the trustee will keep their promise and the willingness to be vulnerable [41]. Inter-organisational trust is the extent to which trust is placed in a third party organisation by the consumer organisation.

A number of trust types can be considered when determining the trust building relationships in cloud computing transactions such as; Socio-technical system trust which is the trust in the infrastructure and 
the environment, Agency trust which is the trust in the agent and in mediating agents; Trust in in the potential service providers, Trust in institutional warrantors and regulatory authorities [45].

From the above definitions and trust approaches, it can be concluded that there is no consensus on the definition of trust. Due to the plethora of trust definitions, it is important to state our definition of trust in the context of this study. In this study, we define trust in cloud computing by SMEs from an adaptation of [46] [41], as the belief of an SME (trustor) that it is worthy of making itself vulnerable to the actions of a cloud service provider (trustee) based on the expectation that the trustee will provide cloud services as per the contract agreed to, irrespective of the inability of the SME to monitor or control the actions of the cloud service provider. The more the interdependence of the trustor to the actions of the trustee, the more the need for trust. This is a multi-level trust, consisting of trust in the institutions, transaction trust, service trust and technology trust [46]. This multi-level perspective of trust is linked with the identified adoption drivers from extant literature as listed in table 2 below and is one of the most frequently cited definitions of trust in inter-organisational trust literature [41]. In our view, this definition of trust is appropriate in this context since it refers to all the dimensions of trust which the SME decision maker is concerned about.

\begin{tabular}{|l|l|l|l|l|}
\hline $\begin{array}{c}\text { Trust } \\
\text { categori } \\
\text { es }\end{array}$ & \multicolumn{1}{|c|}{ Description } & \multicolumn{1}{|c|}{$\begin{array}{c}\text { Adoption } \\
\text { related } \\
\text { constructs }\end{array}$} & Sub-Constructs & Sources \\
\hline $\begin{array}{l}\text { Institutio } \\
\text { nal trust }\end{array}$ & $\begin{array}{l}\text { Government and } \\
\text { regulatory bodies } \\
\text { governing the } \\
\text { institutional env. }\end{array}$ & $\begin{array}{l}\text { Normative } \\
\text { pressures and } \\
\text { coercive } \\
\text { pressures }\end{array}$ & $\begin{array}{l}\text { SLAs, contracts, accreditation, approvals, } \\
\text { guarantees and legal requirements }\end{array}$ & {$[47][48]$} \\
\hline $\begin{array}{l}\text { Service } \\
\text { trust }\end{array}$ & $\begin{array}{l}\text { Cloud services } \\
\text { characteristic that } \\
\text { promote adoption }\end{array}$ & $\begin{array}{l}\text { Relative } \\
\text { advantage, } \\
\text { compatibility }\end{array}$ & $\begin{array}{l}\text { Band width, reliability, brand reputation, } \\
\text { service quality, flexibility, customisation, } \\
\text { competitiveness and availability, }\end{array}$ & {$[49][50]$} \\
\hline $\begin{array}{l}\text { Transacti } \\
\text { on trust }\end{array}$ & $\begin{array}{l}\text { Attributes that are } \\
\text { cost effective for } \\
\text { consumers }\end{array}$ & $\begin{array}{l}\text { Transaction } \\
\text { cost, ROI }\end{array}$ & $\begin{array}{l}\text { Payment flexibility, pricing transparency, } \\
\text { refund policy, fines and penalties }\end{array}$ & {$[52][53]$} \\
\hline $\begin{array}{l}\text { Technolo } \\
\text { gy trust }\end{array}$ & $\begin{array}{l}\text { Technology and } \\
\text { software } \\
\text { characteristics }\end{array}$ & $\begin{array}{l}\text { Security, } \\
\text { privacy, } \\
\text { complexity }\end{array}$ & $\begin{array}{l}\text { Network quality, transmission speeds, } \\
\text { security, digital certificate, public-key } \\
\text { cryptography, integrity, confidentiality, } \\
\text { authenticity, nonrepudiation }\end{array}$ & {$[54][48]$} \\
{$[55][56]$}
\end{tabular}

Table 2: Linking categories of trust with adoption constructs.

Table 2 above demonstrate the link between the categories of trust and adoption constructs from various adoption theories such as DOI theory, TCE theory, institutional theory and Information security theory.

\subsection{Information Security Theory}

Most organisations need information to operate and any disruption to information from a security breach may lead to significant business risks [57]. Information security theory has as goals to mitigate the threats of weak or lack of confidentiality, integrity and availability of information. Various researchers have conceptualised information security theory, one school of thought considers it as a process of securing the computers that process and store information [58], others describe it as a capability and a framework [59]. This study conceptualises information security from the perspective of inter-organisational relationships. The proposed information security theory in this study suggests that there is a faceless inter-organisational transaction such as the adoption and use of cloud computing, The motivation behind attempts to secure customer information against threats in these transactions depends on the hardware and software controls put in place by the service provider and adherence to 
these control processes by the consumer. This theory draws from [58] who considers cloud security objectives to be the availability, integrity and confidentiality of an organisation's assets including networks, infrastructure, business information and people [58]. The cloud user will trust a service provider that has demonstrated strong security controls of its services. The security of cloud services transactions depends on the secure functioning of the make-up of the technology hardware, software and the security of the data stored and transmitted through it.

\subsection{Characteristics of Other considered Theories}

Transaction Cost Theory (TCT) is used to understand the limitations of organisations alternative production and transaction costs such as monitoring, controlling and managing transactions in a relationship [61] [35]. TCT by Williamson [61] proposes the analysis of alternative cost of conducting inter-organisational contractual transactions relative to the others forms of transactions. The variables to consider are; uncertainty, transaction frequency, asset specificity and opportunism. The more the trust in the provider, the less the negotiating cost, less initiating cost and less monitoring and control cost.

Institutional Theory proposed by DiMaggio [8] suggests that any change in the organisation is as a result of pressures from other organisations for it to conform. The reason for conformance is driven by the desire to be accepted, gain status and support. According to DiMaggio [8], the three pressures to gain conformance are; mimetic, coercive and normative. Mimetic pressures enable organisations to become like other similar organisations over time by imitating their behaviour especially competitors [19]. Influential and dominant customers, suppliers, government agencies, regulatory bodies and industry experts exert coercive pressures towards organisations [8]. The consensus from a group of organisations with similar values generate normative pressures [25]. The pressures influence SME intension to adopt cloud computing and considered in this research.

The organisational context of the SME organisational characteristics that contribute to the decision to adopt a new technology such as cloud computing technology have been found to include; organisational size, turnover, technical knowledge and structure [62].

\section{Conceptual Model and Hypotheses}

The proposed conceptual model for this study integrates four well supported theoretical lenses: the DOI theory by Rogers [35], transaction cost economics (TCE) by Williamson [61], institutional theory by DiMaggio [8], IS Security theory adapted from Von Solms \& Van Niekerk [58], organisation literature [10] and trust theories adapted from McKnight \& Rousseau [41] [3]. The integration of these theories enhances the explanatory power of the proposed conceptual model. 


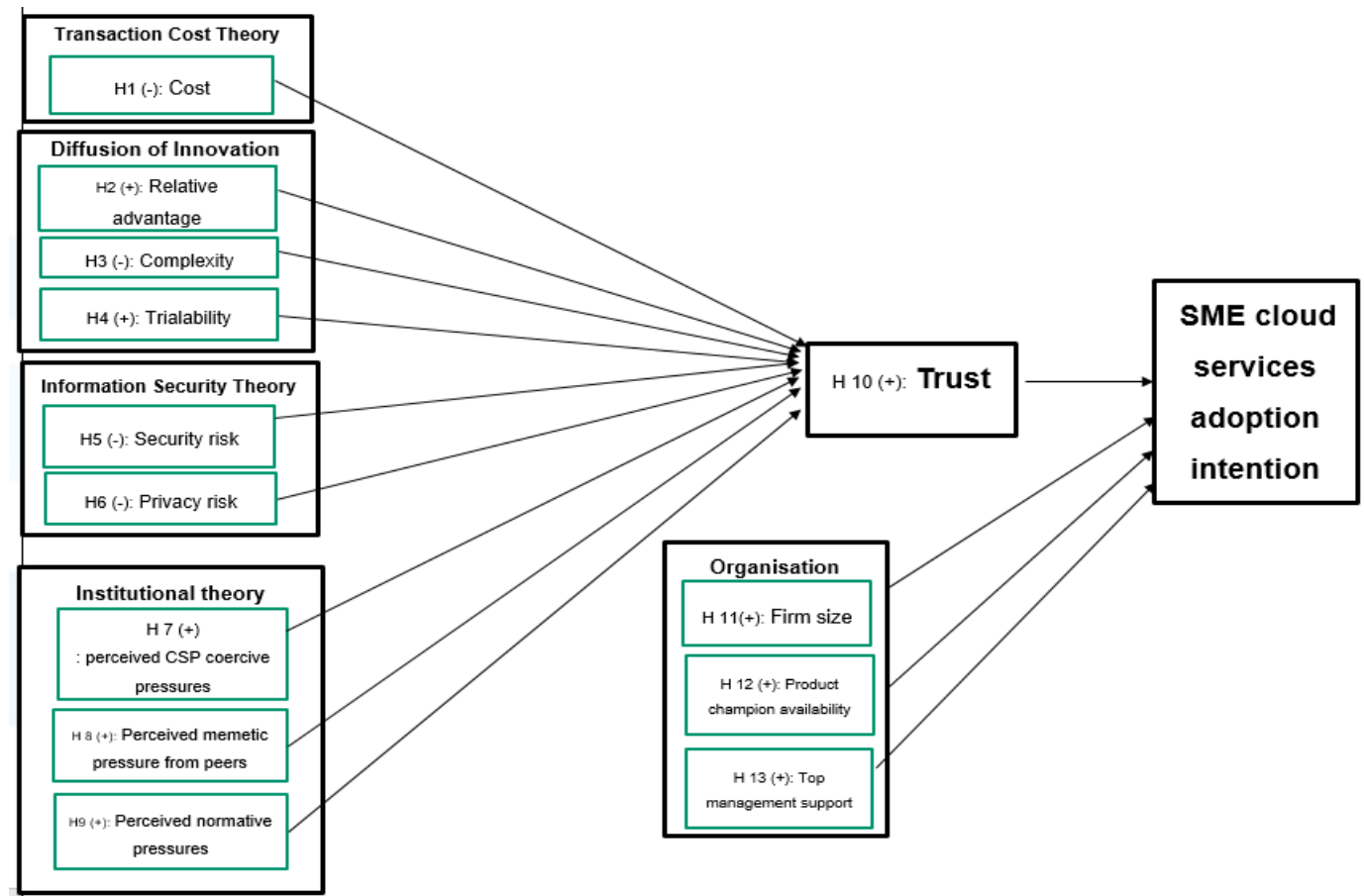

Figure 2: A conceptual model of the study

The conceptual model proposed in figure 2 above has considered critical trust constructs and how these relates to the decision behaviour of SME cloud consumers towards the adoption of cloud services. From the above empirical studies, as outlined in table 1 above, this study argues that factors that influences SME decision to adopt cloud technology are relative advantage, cost, trust, compexity, compatibility, trialability, top management support, security, privacy, technical capability, competitor and trading partner pressure. We propose that trust not only has a direct effect on adoption of cloud computing but also mediates the other adoption factors. Extant literature has offered little understanding of the mediating effects of trust in new technology adoption research [9], this study hopes to improve the understanding of how the different dimensions of trust (institutional, transactional and organisational) enhances cloud computing adoption by SMEs in developing economies [47] [48] [52] [53] [44] [54] [48] [55] [56].

\subsection{Hypotheses of Transaction Cost Characteristics}

Transaction cost theory: Many studies have suggested that cloud computing technology has the likelihood of reducing the total technology cost of the organisation which includes the negotiating cost, setting-up cost, maintenance cost, upgrade and training costs. According to [63], negotiation costs are lower where inter-organisational trust are high. [19] investigated Indian SMEs adoption decisions and found cost reduction as a significant determinant based on TCE theory. Other studies conducted in Ghana, Nigeria, Ethiopia, Malaysia and South Africa also indicates that price reduction is a determining factor in trusting new technology [29] [30] [31] [32]. The more trust between consumers of cloud technology and cloud service providers the less the cost in monitoring and controlling performance and contracts.

H1: Transaction cost is negatively related to the trust in cloud computing services. 


\subsection{Hypotheses of Innovation Characteristics}

According to Rogers [35] the bigger the perceived relative advantage of innovation by an organisation, which can be financial or non-financial, the lower the uncertainty, higher trust and faster the level of its adoption will be. Hence

H2: Relative advantage has here is a positive relationship with the trust in cloud computing services.

Complexity is a multidimensional construct within SMEs and refers to the scope the implementation of the new technology, the technical sophistication linked with its understanding and the degree of novelty [64]. The perception of technical sophistication reduces the trust in the technology. Trust is an instrument to reduce the complexity of user behaviour in a situation where they must cope with uncertainty. This uncertainty is significantly reduced if users of a new technology get a chance to test its functionality. Hence the hypotheses that:

H3: Complexity has a negative relationship with the trust in cloud computing services

H4: Trialability has a negative relationship with the trust in cloud computing services

\subsection{Hypotheses of Information Security Theory Characteristics}

Many studies have investigated the relationship between trust in cloud computing services and data privacy[23] [6] [7]. The reputation and privacy policies of cloud service providers has been found to influence the trust consumers have in the services of these providers [43]. Pavlou [65] developed an empirically supported study to investigate how perceived privacy and perceived security promotes trust in e-commerce transactions Hence this study can hypothesis that

H5: There is a negative relationship between security risk and the trust in cloud computing services

Data privacy within cloud computing puts permission controls and administrative access especially for cloud as a service are managed by the cloud provider, the SME may not be aware when their data is being breached unless notified by the provider. Strong encryption mechanisms, credentials and authorisation policies on sensitive and personal data can improve the level of trust consumers of cloud computing services. This study can hypothesis as follows:

H6: There is a negative relationship between privacy risk and the trust in cloud computing services

\subsection{Hypotheses of Institutional Theory Characteristics}

Empirical scholarships suggest that coercive pressures from cloud service providers as a result of its position of power has an influence on the CSU's trust as a buyer of these services [19] [9].

The following hypothesis is proposed:

H7: The cloud services consumer's perceived coercive pressures from cloud service providers' influence is negatively associated with the trust in cloud computing services.

When organisations that compete with each other, practice the same set of values and norms, the more likely they will trust each others' decisions. The perception of success by peers after adopting cloud computing services, increases the trust in this by other organisations in the same peer group. Hence the hypotheses that follows:

H8: There is a positive relationship between the memetic pressure from similar SME competitors and the trust in cloud computing services by other SMEs

H9: There is a positive relationship between the normative pressure from similar SME competitors and the trust in cloud computing services by other SMES. 


\subsection{Hypotheses of Trust Theory Characteristics}

According to the argument by McKnight [5], consumers will be more likely to trust third parties if the third party acts in an environment they perceive as being trustworthy such as the regulatory and legal environment. Institutional trust mechanisms such as laws, contracts and reputational sanctions are a deterrent to opportunistic behaviour by third parties [61]. Consumers readily trust Uber and Airbnb based on the institutional trust mechanisms such as structural assurances and situational normality around these services. We follow this argument to hypotheses that:

H10: There is a positive relationship between the trust in cloud computing services and the intention to adopt cloud services by SMEs.

\subsection{Hypotheses of Organisational Theory Characteristics}

Smaller organisations such as SMEs though more flexible, have less resources to readily make the decision to adopt new technology, but when the benefits are apparent, they are more receptive towards it. The provision of adequate resources and support for the implementation of new technology such as cloud computing by top management is critical for its adoption due to its complexity [23] [26]. Previous research has also found a product expert in the new technology to be a determinant for the adoption of new technology [6] [4].

Hence, we can make the following hypotheses;

H11: There is a positive relationship between the size of the organisation and the intention to adopt cloud services by SMEs.

H12: There is a positive relationship between the availability of a product champion and the intention to adopt cloud services by SMEs.

H13: There is a positive relationship between Top management support and the intention to adopt cloud services by SMEs.

In the proposed integrated conceptual model, the cost factor from transaction cost theory is a critical factor. Relative advantage, triability and complexity are the most critical factors from innovation diffusion theory. Key information security theory factors include security and privacy, and key institutional theory factors influence as a result of peers normative and memetic pressures and cloud service providers coercive pressures.

Other contextual factors include firm size, top management support and product champion. The various relationships are presented in figure 1 above.

\section{Conclusion, Limitation and Future Work}

This paper provides a broad overview of the literature on the critical factors that could be used to assess the adoption of cloud computing services by SMEs in South Africa. It builds on and supplements the theory of diffusion of innovation (DOI) by offering a cross-fertilization with different theories to explain and predict patterns of use in the SME context. After a deep analysis of the use, extensions, and limitations of DOI theory, this study argued that trust is a dynamic mechanism through which the adoption variables can influence the decision to adopt cloud compting. From initiation trust (step 1: knowledge), to building trust (step 2: persuations), to maturity or declining trust (step3: decisions). This study then develops and proposes an integrated conceptual model that incorporates critical factors from the DOI theory, institutional theory, transaction cost theory, organisational theory, information system security and privacy theory, and trust theories. A multi-level (institutional, transactional, service and 
technology trust) definition of trust is proposed for SME-CSP relationships. This study also demonstrates the link between the categories of trust and adoption constructs from various adoption theories such as DOI theory, TCE theory, institutional theory and Information security theory. We expect that this synthesis of concepts from these diverse fields of research will all have a bearing on the complex issue of cloud services adoption and should improve our overall ability to explain and predict patterns of cloud services use in the SME context. It is hoped that our mapping of this vast conceptual terrain and the proposed model that was developed will offer both theoretical insights and practical value in future SME cloud adoption research. This study contributes to a deeper understanding of the determinants of cloud computing adoption by SMEs in developing economies by providing a more holistic theoretical lens, that draws on different theoretical approaches that seek to improve the adoption of cloud computing services. In future studies, this model will be further explored in case studies and refined, applied and tested in survey research. Finally, we call for broadening the conceptualization of organizational adoption of technologies to better explain the adoption of cloud services in the SME context.

\section{References}

[1] . Lambert, «The Four Challenges of the Fourth Industrial Revolution.,» Market Mogul., LA, 201'

[2] J. Kima, Y. I. Songb, S. Braynovc ve H.R. Rao, «A multidimensional trust formation model in -to-C e-commerce: a conceptual framework and content analyses of academia/ practitioner :rspectives,» Decision Support Systems, cilt 40, p. 143- 165, 2005.

[3] H. McKnight, «Trust in Information Technology,» Management Information Systems, cilt 7, p. 19-331, 2005.

[4] Hinde ve J.-P. V. Belle, «Cloud Computing in South African SMMEs: Risks and Rewards for aying at Altitude,» International Research Journal of Computer Science Engineering and splications, cilt 1, no. 1, 2012.

[5] Mcknight ve N. Chervany, «What Trust Means in E-Commerce Customer Relationships: An terdisciplinary Conceptual Typology.,» International Journal of Electronic Commerce,, cilt 6, J. 2, pp. 35-59, 2002.

[6] Alhammadi, C. Stanier ve A. Eardley, «The determinants of cloud computing adoption in Saudi rabia,» 2013

[7] Karkonasasi, A. Baharudin, B. Esparham ve S. Mousavi, «Adoption of cloud computing among Iterprises in Malaysia by,» Indian Journal of Science and Technology, cilt 9, no. 38, 2016.

[8] J. DiMaggio ve W. W. Powell, «The Iron cage revisited: Institutional isomorphism and collective tionality in organizational fields,» American Sociological Review, cilt 48, no. 2, p. 147-160, 1983.

[9] . Ke, H. Liu, K. K. Wei, J. Gu ve H. Chen, «How do mediated and non-mediated power affect ectronic supply chain management system adoption? The mediating effects of trust and stitutional pressures.,» Decision Support Systems, cilt 46, no. 4, p. 839-851, 2009.

[10] Oliveira ve M. F. Martins, «Literature review of information technology adoption models at firm vel,» The Electronic Journal Information Systems Evaluation, cilt 14, no. 1, p. 110-121., 2011.

[11] Giraud, «How Cloud is Driving the Next Industrial Revolution,» Oracle EMEA, tps://www.oracle.com/uk/cloud/paas/features/next-industrial-revolution.html , 2018.

[12] \&. G. T. Mell, «The NIST drfinition of cloud computing,» US Department of Commerce, MD, 11 . 
Modeling the adoption of cloud computing to assess South African SMEs:... K. Ayong and R. Naidoo

[13] K. E. Gefen ve D. Straub, «Trust and TAM in Online Shopping,» An Integrated Model. MIS uarterly, cilt 27, no. 1, pp. 51-90, 2003.

[14] D. Lee ve K. A. See, «Trust in Automation: Designing for Appropriate Reliance,» Human xctors, cilt 46, no. 1, pp. 50-80, 2004.

[15] Oliveira, M. Thomas ve M. Espadanal, «Assessing the determinants of cloud computing loption: An analysis of the manufacturing and services sectors,» cilt 51, no. 5, 2014.

[16] Hsu ve J. Lin, «Factors affecting the adoption of cloud services in enterprises,» Information stems and e-Business Management, pp. 1-32, 2015.

[17] I. Chang, «A proposed framework for cloud computing adoption. In Sustainable Business: oncepts, Methodologies, Tools, and Applications,» IGI Global, pp. 978-1003, 2019.

[18] Low, Y. Chen ve M. Wu, «Understanding the determinants of cloud computing adoption,» dustrial management \& data systems, cilt 111, no. 7, pp. 1006-1023, 2011.

[19] M. Bhat, «Adoption of Cloud Computing by SMEs in India: A study of the Institutional Factors,» hicago, 2013.

[20] Vidhyalakshmi ve V. Kumar, «Determinants of cloud computing adoption by SMEs,» ternational Journal of Business Information Systems, cilt 22, no. 3, pp. 375-395, 2016.

[21] Priyadarshineea, R. D. Rautb, M. K. Jhac ve S. S. Kambleb, «A cloud computing adoption in dian SMEs: Scale development,» Journal of High Technology Management Research 28 (2017) ?1-245, cilt 28, pp. 221-245, 2017.

[22] Gupta ve J. Seetharaman, «The usage and adoption of cloud computing by small and medium,» ternational Journal of Information Management, cilt 33, no. 5, pp. 861-874, 2013.

[23] H. D. Gangwar ve R. Ramaswamy, «Understanding determinants of cloud computing adoption ing an integrated TAM-TOE model.,» Journal of Enterprise Information Management, cilt 28, ). 1, pp. 107-130, 2015.

[24] . El Garah, A. Berrado ve N. El Ouarti, «Cloud computing adoption in an emerging market,» 10 .

[25] R. Tehrani ve F. Shirazi, «Factors influencing the adoption of cloud computing by Small and edium size Enterprises (SMEs),» 2014.

[26] N. Makena, «Factors that affect cloud computing adoption by SMEs in Kenya,» International urnal of Computer Applications Technology and Research, cilt 2, no. 5, pp. 517-521, 2013.

[27]. I. Z. Bellaaj ve M. Albugami, "The continued use of e-learning system: An empirical vestigation using UTAUT model at the University of Tabuk.,» Journal of Theoretical and splied Information Technology, cilt 72, no. 3, pp. 464-474, 2015.

[28] Saedi ve N. A.Iahad, «Developing an Instrument for Cloud Computing Adoption by Small and edium-sized enterprises,» 2016.

[29] Dahiru, J. M. Bass ve I. K. Allison, «Cloud Computing Adoption in sub-Saharan Africa: An nalysis using Institutions and Capabilities,» 2014.

[30] . Yaokumah ve A. R.A, «Examining the contributing factors for cloud computing adoption in a :veloping country,» International Journal of Enterprise Information Systems, cilt 13, no. 1, pp. 7 - 37, 2017.

[31] Pathan, Z. Jianqiu, U. Akram, M. Khan, Z. Latif ve T. M.Z, «Innovation-diffusion determinants cloud-computing adoption by Pakistani SMEs,» Journal Human Systems Management, cilt 36, ). 3, pp. 197 - 209, 2017.

[32] Qian, A. Baharudin ve K.-J. A., «Factors affecting the adoption of enterprise resource planning (RP) on cloud among small and medium enterprises (SMES) in Penang, Malaysia,» Journal of 
Modeling the adoption of cloud computing to assess South African SMEs:... K. Ayong and R. Naidoo

ieoretical and Applied Information TechnologJournal of Theoretical and Applied Information zchnology, cilt 88, no. 3, pp. 398 - 409, 2016.

[33] F.D., «Perceived usefulness, perceived ease of use, and user acceptance of information chnology,» MIS Quarterly, cilt 13, p. 319-340, 1989.

[34] Ajzen, «The theory of planned behavior,» Organisation behaviour Humun Decision Process, cilt ), p. 179-211, 1991.

[35] M. Rogers, Diffusion of innovations, New York: 4th Edition, 1995.

[36]. M. Mohammadi, R. Poursaberi ve M. R. Salahshoor, «Evaluating the adoption of evidenceısed practice using Rogers's diffusion of innovation theory: a model testing study,» Health romotion Perspectives, cilt 8, no. 1, pp. 25-32, 2018.

[37] M. Morgan ve S. D. Hunt, «The Commitment-Trust Theory of Relationship Marketing.,» Journal Marketing, cilt 58, no. 3, p. 20, 1994.

[38] Singh ve D. Sirdeshmukh, «Agency and trust mechanisms in consumer satisfaction and loyalty dgments,» Journal of the Academy of Marketing Science, cilt 28, no. 1, pp. 150-167, 2000.

[39] . Hollis, Trust within Reason,, Cambrige, UK: Cambridge University Press, 1998.

[40] Dirks ve D.L. Ferrin, «Trust in leadership: meta-analytic findings and implications for research Id practice,,» Journal of Applied Psychology, 2001.

[41] M. Rousseau, S. B. Sitkin, R. S. Burt ve C. Camerer, «Not so different at all: A cross disziplinary ew of trust.,» Academy of Management Review, cilt 23, no. 3, pp. 393-404, 1998.

[42] Gambetta, Trust: Making and Breaking Cooperative Relations, Basil Blackwell, 1990.

[43] Jarvenpaa, N. Tractinsky ve L. Saarinen, «Consumer Trust in an Internet Store: A CrossCultural alidation,» Journal of Computer Mediated Communication, cilt 5, no. 2, pp. 1-37, 1999.

[44] Pugliese, « SysTrust and WebTrust: technology assurance opportunities,» The CPA Journal , It 70, no. 11, p. 28-33, 2000.

[45] Castelfranchi ve R. Falcone, «Socio-Cognitive Theory of Trust,» National Research Council stitute of Psychology, Rome, 2000.

[46] H. McKnight, M. Carter, J. B. Thatcher ve P. F. Clay, «Trust in a Specific Technology: An vestigation of Its Components and Measures,» ACM Transactions on Management Information stems, cilt 2, no. 2, pp. 12-25, 2011.

[47] Ba ve P. Pavlou, «Evidence of the effect of trust building technology in electronic markets: price 'emiums and buyer behavior,,» Management Information Systems Quarterly, cilt 26, no. 3, p. 13-268, 2002.

[48] Benassi, «TRUSTe: an online privacy seal program,» Communications of the ACM, cilt 42, no. p. 56- 59, 1999.

[49] Alba, C. Janiszewski, J. Lutz, J. Lynch, A. Sawyer, A. Weitz ve S. Wood, «Interactive home opping: consumer, retailer, and manufacturer incentives to participate in electronic arketplace,,» Journal of Marketing, cilt 61, p. 38- 53, 1997.

[50] Chow ve Holden, «Toward an understanding of loyalty: the moderating role of trust,» Journal of anagerial Issues, cilt 15, no. 3, p. 275-298, 1997.

[51] Hill, «Cooperation, opportunism, and the invisible hand: implications for transaction cost eory,» Academy of Management Review , cilt 15, p. 500-513, 1990.

[52] Eagly ve S. Chaiken, The Psychology of Attitudes,, New York: Harcourt, Brace Jovanovich,, 193. 
Modeling the adoption of cloud computing to assess South African SMEs:... K. Ayong and R. Naidoo

[53] Park, «The global transformation of financial services,» European Business Journal, cilt 11, no. pp. 7-16, 1999.

[54] . Benantar, «The Internet public key infrastructure,,» IBM Systems Journal , cilt 40, no. 3, p. 648i5, 2001.

[55] Bhimani, «Securing the commercial internet,»» Communications of the ACM, cilt 39, no. 6, p. ) $35,1996$.

[56] Jones, Wilikens ve M. Morris, «Trust requirements in ebusiness,» Communications of the ACM, It 43 , no. 12 , p. 81-87, 2000.

[57] Cavusoglu, H. Cavusoglu ve S. and Raghunathan, «Economics of It Security Management: Four uprovements to Current Security Practices,» The Communications of the Assoc for Information stems, cilt 14, no. 1, pp. 37-43, 2004.

[58] Von Solms ve J. Van Niekerk, «From Information Security to Cyber Security,» Computers \& 'curity, cilt 38, pp. 97-102, 2013.

[59]. Siponen ve H. Oinas-Kukkonen, «A Review of Information Security Issues and Respective esearch Contributions,» ACM Sigmis Database, cilt 38, no. 1, pp. 60-80, 2007.

[60] rropean Commission, «Expert Group Report Meeting on Cloud Computing,» Directorate General r Information Society and Media, Brussels, 2010.

[61] E. Williamson, The Economic Institutions of Capitalism, New York: The Free Press, 1985.

[62] Oliveira ve M. Martins, «Understanding e-business adoption across industries in European untries,» Industrial Management \& Data Systems, cilt 110, pp. 1337-1354, 2010.

[63] Zaheer, B. McEvily ve V. Perrone, «Does Trust Matter - Exploring the Effects of terorganizational and Interpersonal Trust on Performance,» Organization Science, cilt 9, no. 2, 141-159, 1998.

[64] Gopalakrishnan ve F. Damanpour, «Patterns of generation and adoption of innovation in ganizations: Contingency models of innovation attributes,» Journal of Engineering and ?chnology Management, cilt 11, pp. 95-116, 1994.

[65] Pavlou ve R. Chellappa, «The Role of Perceived Privacy and Perceived Security in the evelopment of Trust in Electronic Commerce Transactions,» Electronic Commerce Metrics, 01 . 